\title{
Potential imprint of Spörer and Maunder solar minima on coral skeleton carbon isotopes
}

T. Ourbak ${ }^{1,2,{ }^{*}}$, B. Malaizé ${ }^{1}$, and T. Corrège ${ }^{1,2}$

${ }^{1}$ Université Bordeaux 1, UMR CNRS 5805 EPOC, Avenue des facultés, 33405 Talence cedex, France

${ }^{2}$ UR055 Paleotropique, Institut de Recherche pour le développement (IRD), 32 avenue Henri Varagnat, 93143 Bondy cedex, France

"now at: College of Marine Science, University of South Florida, 1407 Avenue South, St. Petersburg, FI 33701, USA

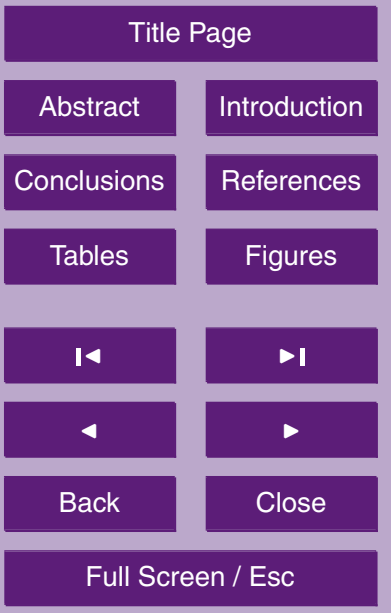

Received: 6 September 2007 - Accepted: 18 September 2007

- Published: 27 September 2007

Correspondence to: T. Ourbak (tourbak@ marine.usf.edu) 


\section{Abstract}

Despite being routinely measured with $\delta^{18} \mathrm{O}$ in corals, records of $\delta^{13} \mathrm{C}$ are seldom presented in paleoceanographic studies. Numerous factors influence the biologicallymediated fractionation of carbon isotopes during skeletogenesis, resulting in a complex 5 behaviour of this tracer. Here we present a long coral $\delta^{13} \mathrm{C}$ series, dating back to 1475 , and showing the potential impact of solar activity. We note a significant decrease of $\delta^{13} \mathrm{C}$ during the Spörer and Maunder minima. We argue for a change in metabolical processes, from an autotrophical pattern to a more heterotrophical mode of feeding guided by change in sun irradiation. In addition, nearby volcanic eruptions might also 10 have an impact and cause $\delta^{13} \mathrm{C}$ shifts, depending on the dust load associated with the eruption. Following previous work, we advocate the systematic presentation of $\delta^{13} \mathrm{C}$ vs. $\delta^{18} \mathrm{O}$ plots in coral studies to identify whether isotopic fractionation might have been affected by change in mode of feeding.

\section{Introduction}

15 Aragonite deposited by hermatypic corals is usually depleted in ${ }^{13} \mathrm{C}$ relative to ambient seawater as a result of kinetic and metabolic fractionation (Kieth and Weber 1965). Despite numerous field and laboratory investigations over the years, variations of coral $\delta^{13} \mathrm{C}$ is still difficult to interpret, chiefly because it is influenced by complex physiological and environmental parameters. Photosynthetic activity of zooxanthellae and respiration (Swart 1983; McConnaughey 1989), level of zooplankton availability (ReynaudVaganay et al., 2001; Grottoli 2002), insolation (Swart et al., 1996), cloud cover (Fairbanks and Dodge, 1979), spawning (Gagan et al., 1994), plankton blooms (Felis et al., 1998) or depth (Carriquiry et al., 1994) may be responsible for $\delta^{13} \mathrm{C}$ change in corals. In addition the thermo-dependence of carbon isotopes partitioning between solution

In theory, corals possess a capability for mixotrophy and can acquire carbon by two

3, 1021-1035, 2007

\section{Solar minima and coral carbon isotopes}

T. Ourbak et al.

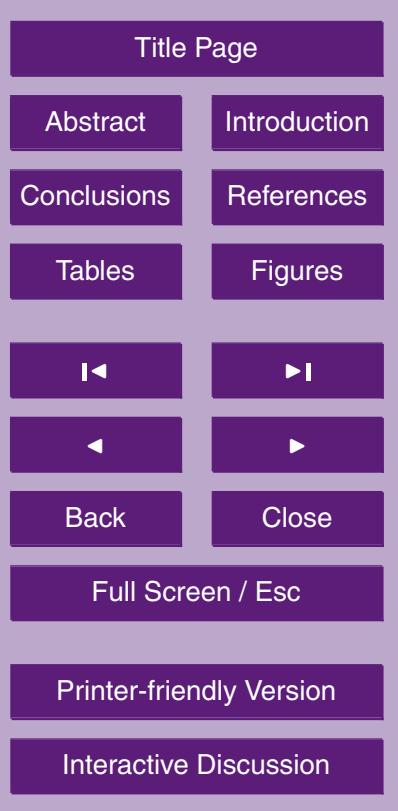


ways. $\delta^{13} \mathrm{C}$ is affected by the two principal feeding modes of the animal: capture of zooplankton by polyps (heterotrophic process) and receipt of photosynthetic products from the endosymbiotic algae, i.e. the zooxanthellae (autotrophic process).

Concerning heterotrophy, we will follow the hypothesis that ingestion of zooplankton 5 decrease $\delta^{13} \mathrm{C}$ values in coral skeleton because zooplankton has depleted $\delta^{13} \mathrm{C}$ values (typically -15 to $-25 \%$ o Rau et al., 1990; Grottoli, 2002).

Autotrophy is related to photosynthesis activity, a light-driven metabolic reaction that causes isotopic fractionation via zooxanthellae. It has been shown that carbon isotopes in corals were strongly influenced by solar irradiance levels (McConnaughey, 1989; Mc-

10 Connaughey et al., 1997; Boiseau et al., 1998; Reynaud-Vaganay et al., 2001). The more important the photosynthetic activity is the more ${ }^{12} \mathrm{C}$ will be used by zooxanthellae. Consequently, the more ${ }^{13} \mathrm{C}$ (relative to ${ }^{12} \mathrm{C}$ ) will be available for calcification and the more positive the $\delta^{13} \mathrm{C}$ might be recorded in coral skeleton. The hypothesis described above is widely accepted (Swart, 1983; McConnaughey, 1989; Grottoli, 2000), but the complexity lies in the fact that numerous factors can affect light availability. Thus, on top of processes occurring in the atmosphere, water depth (Carriquiry et al., 1994), turbidity (Anthony and Fabricius, 2000) or coral topography (Cohen and Hart, 1997) could influence carbon uptake.

Past studies on coral $\delta^{13} \mathrm{C}$ dealt with daily (Weber and Woodhead, 1971) to seasonal 20 variation (Swart et al., 1996) in light level, but no record was long enough to study the possible effect of long-term solar variations. We propose to test the relative influence of past solar variability over a long continuous record of $\delta^{13} \mathrm{C}$ beginning circa 1475 .

\section{Study area, material and methods}

The studied coral comes from lle des Pins $\left(22.3^{\circ} \mathrm{S}, 167.2^{\circ} \mathrm{E}\right)$, the southernmost island of New-Caledonia, in the southwest Pacific Ocean. Large coral heads and relatively long series of instrumental data such as temperature and salinity have contributed to the success of New Caledonia as a coral sampling site (Beck et al., 1992; Quinn et al.,

\section{Solar minima and coral carbon isotopes}

T. Ourbak et al.

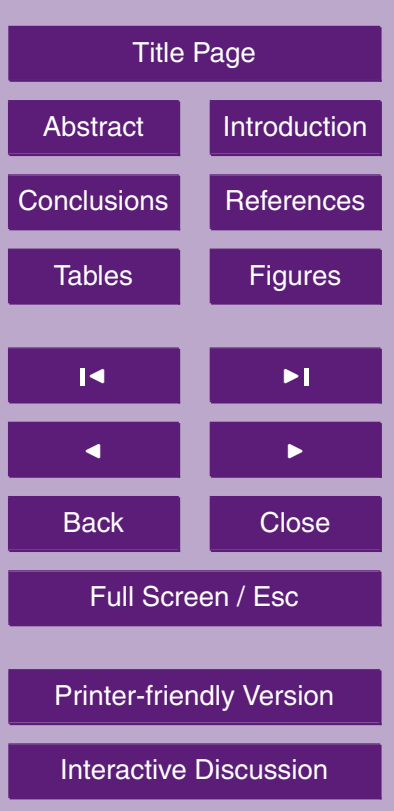


1998; Corrège et al., 2001; Ourbak et al., 2006).

A $7 \mathrm{~m}$ high massive Porites coral was sampled in August 1999 and February 2003 on lle des Pins reef. The core recovered in 2003 was primarily used to sample the years necessary to calibrate coral data against local environmental parameters. Chronol5 ogy of the longest core was established by growth bands counting on X-radiographs, which also helped to choose the optimal sampling transects. Coral skeleton powder was recovered at quasi-monthly resolution for calibration purpose over 6 years, then 2 samples per year were extracted for the whole core. Analyses were conducted on a Micromass Optima isotope ratio mass spectrometer at UMR 5805 EPOC (Université

10 Bordeaux 1). All values are reported in standard delta notation relative to the VPDB isotopic standard using the conventional notation. Precision calculated for 373 replicates of NBS 19 international standard was better than $0.05 \%$ of $\delta^{13} \mathrm{C}$ and $0.07 \%$ ofor $\delta^{18} \mathrm{O}(1 \sigma)$

\section{Results and discussion}

\section{$15 \quad 3.1$ Modern behaviour}

Figure 1 shows six years of $\delta^{18} \mathrm{O}$ and $\delta^{13} \mathrm{C}$ record, together with daily solar irradiance measured since 1996 at Moué, less than 10 kilometres from the coring site. Chronology was established using $\delta^{18} \mathrm{O}$ record for which clear annual variations mainly driven by change in sea surface temperature and salinity are visible. Both solar radiation and $\delta^{13} \mathrm{C}$ reveal the same seasonal-shaped pattern, although some discrepancies are visible (Fig. 1). Table 1 presents correlation coefficients $(r)$ between the data, including SST. For example, regression between $\delta^{13} \mathrm{C}$ and solar irradiation yields a correlation coefficient $(r)$ of $0.54(n=74 ; p<0.001)$, denoting a significant relationship between solar activity and carbon isotope signal in coral skeleton. One has to keep in mind that the annual cycle inflates the correlation between the two series (computed anomalies decrease $r$ to 0.36 ) and other parameters vary over the same timescale and could influ-

3, 1021-1035, 2007

\section{Solar minima and coral carbon isotopes}

T. Ourbak et al.

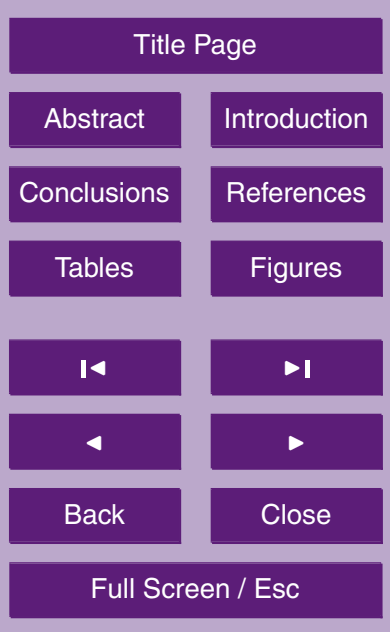

Printer-friendly Version

Interactive Discussion 
ence $C$ incorporation. Nevertheless, this result confirms previous studies (Boiseau et al., 1998, among others) and indicates that this New Caledonia coral has the potential to bring information on past solar activity.

\subsection{Paleoclimatic interpretations}

$5 \quad 3.2 .1$ Long trend

Raw $\delta^{13} \mathrm{C}$ measurements ranged from $-3.43 \%$ to $0.67 \%$ o with a mean of $-1.17 \%$. Figure 2 presents $\delta^{13} \mathrm{C}$ variations along the core together with reconstructed solar irradiance from Bard et al. (2000) and Lean et al. (1995) together with a $\delta^{13} \mathrm{C}$ record form Amedee Island (Quinn et al., 1998).

10 The first striking feature is the relationship between centennial increase of solar irradiance $\left(\sim 1.13 \mathrm{~W} \cdot \mathrm{m}^{2} /\right.$ century) and long term $\delta^{13} \mathrm{C}$ increase between 1475 and about 1860 ( $\sim 0.18 \%$ 。 /century). Then, one can see a $\sim 0.7 \%$ 。 decrease of the $\delta^{13} \mathrm{C}$ signal which could be a coral response to the isotopically light carbon from $\mathrm{CO}_{2}$ added to the atmosphere from fossil fuel burning (oceanic Suess effect). This decrease is ex15 pected from the Suess effect in the subtropical surface ocean ( 0.8\%。 Gruber et al., 1999). Similar decreases are reported in New Caledonia after the pre industrial period, $\sim 0.9 \%$ is recorded in a nearby Porites coral from Amedee lighthouse $\left(22.3^{\circ} \mathrm{S}, 166.3^{\circ} \mathrm{E}\right.$ (Quinn et al., 1998), Fig. 2 and discussion below) and in a demosponge at Touho, on the other side of New Caledonia main island $\left(20.4^{\circ} \mathrm{S}, 165.1^{\circ} \mathrm{E}\right.$, Bohm et al., 1996). In 20 addition, the Suess effect has also been recorded in Australian coral $\left(17.5^{\circ} \mathrm{S}, 148.3^{\circ} \mathrm{E}\right.$, Pelejero et al., 2005) and in a coralline sponge from Vanuatu $\left(13.8^{\circ} \mathrm{S}, 167.5^{\circ} \mathrm{E}\right.$, Fallon et al., 2003) arguing for a regional $\delta^{13} \mathrm{C}$ signal.

Early marine diagenesis could complicate the interpretation of the $\delta^{13} \mathrm{C}$ record in corals, especially when dealing with Suess effect (Müller et al., 2004) but SEM images 25 and XRD (not shown here), together with geochemical cross-plot of $\delta^{13} \mathrm{C}$ vs. $\delta^{18} \mathrm{O}$ (Fig. 3, see also Quinn and Taylor, 2006) avoid this hypothesis.

\section{Solar minima and} coral carbon isotopes

T. Ourbak et al.

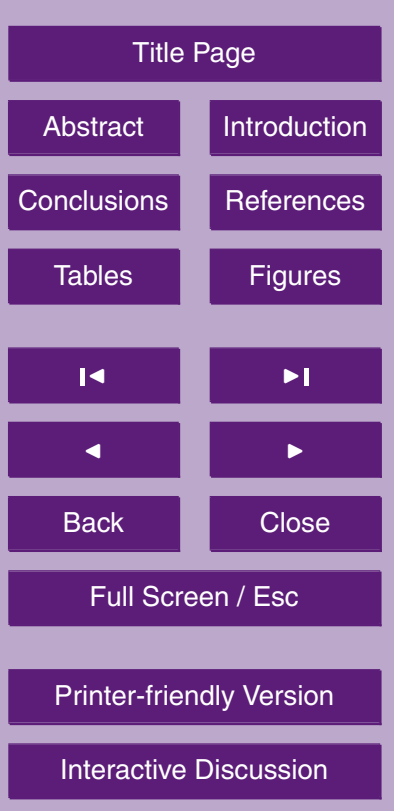




\subsubsection{Centennial event.}

We find on Fig. 2 a first broad negative $\delta^{13} \mathrm{C}$ peak near 1515 (0.78\% from the mean) and a second one (0.94\%。 from the mean) at the beginning of the 1650 's. These peaks are situated at changeover from solar maxima to solar minima. The low $\delta^{13} \mathrm{C}$ 5 values in the coral skeleton might have been driven by low solar activity periods such as the Spörer minimum (which lasted from about 1420 to 1570 AD) and the Maunder minimum (1645-1715), knowing that insolation is one of the main factors controlling photosynthesis.

We propose that, because of insufficient light availability, metabolic processes 10 changed from an autotrophical driven pattern into a more heterotrophical driven pattern, decreasing $\delta^{13} \mathrm{C}$ value. However, we note that the Dalton minimum (1800-1820), which was a shorter and less significant period of lower solar activity, has a less marked $\delta^{13} \mathrm{C}$ signature in our coral record. In theory, $\delta^{13} \mathrm{C}$ values might have stayed low during the entire Spörer and Maunder minima, if metabolic processes had remained the 15 same. Instead, in Fig. $2, \delta^{13} \mathrm{C}$ signature shows a gradual change to more positive values, arguing for a recovery to more classical conditions of feeding for our coral.

To differentiate the preferential metabolic processes, one can plot $\delta^{13} \mathrm{C}$ against $\delta^{18} \mathrm{O}$ (Fig. 3). According to McConnaughey's model (McConnaughey 1989) metabolic processes shift values along the carbon axis, independent of oxygen. Therefore, quasi20 systematic shifts toward more negative values of $\delta^{13} \mathrm{C}$ corresponding to solar minima denote increase of heterotrophy (Fig. 3). Following this method, Risk et al. (2003) showed a specific $\delta^{13} \mathrm{C}$ vs. $\delta^{18} \mathrm{O}$ signature of 'haze' events on Indonesian corals produced by wildfires during an intense El Niño event. Figure 3 confirms that minima in solar activity had an impact on coral mode of feeding. Quantitatively, the mean value 25 for Spörer and Maunder minima (as presented on Fig. 3) are 0.66 and $0.72 \%$ o far from the $\delta^{13} \mathrm{C}$ mean while they are only 0.06 and $0.12 \%$ far from the $\delta^{18} \mathrm{O}$ mean.

Comparison of lle des Pins vs Amedee core shows periods of agreements (the long term trend for example) as well as some discrepancies (e.g. around 1720).

3, 1021-1035, 2007

\section{Solar minima and coral carbon isotopes \\ T. Ourbak et al.}

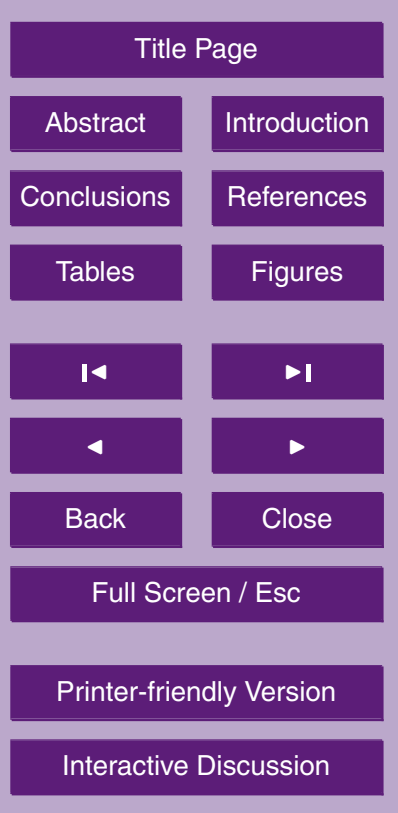


MTM cross spectrum (Ghil et al., 2002) conducted over detrended, normalised (remove the mean and divided by standard deviation over the common 1658-1992 period) Amedee and lle des Pins $\delta^{13} \mathrm{C}$ series have been conducted. Analyses show that the two series share common periodicities centred on 32, 21 and 15 years (at 5 the $90 \%$ interval confidence). In addition, lle des Pins serie shows 11.6 and a broad 60-100 year peaks. This exercise confirms the potentiality for this core to record the Schwabe (11 years), Hale (22 years), and Gleissberg (70-100 years) solar cycles, in addition to other frequencies. The reason why the two coral records do not show the same exact answer to common forcing is not clear. Difference in chronology could be 10 part of the answer. Moreover, it has been shown that over two $\delta^{13} \mathrm{C}$ corals records from Nauru, western tropical Pacific, only one could reflect light level variability (Guilderson and Schrag, 1999). $\delta^{13} \mathrm{C}$ signals in corals have also shown less reproducible patterns than oxygen isotopes or elemental ratios (Guilderson and Schrag, 1999; DeLong et al. 2007). Nevertheless, on a same colony mean $\delta^{13} \mathrm{C}$ value is not significantly 5 changed by sampling resolution (forthnightly to seasonal sampling) or the site of the slice chosen (DeLong et al., 2007). Moreover, the date of settlement of the Amedee coral in 1657 is just after the lowest $\delta^{13} \mathrm{C}$ value of our record for the Maunder minima and one could argue that the nubbin settlement has been facilitated after a period of relative low light availability and a return to more classical conditions.

\subsubsection{Rapid events}

In addition to the low frequency changes in $\delta^{13} \mathrm{C}$ at lle des Pins, short-term events are visible (Fig. 2). We note particularly light $\delta^{13} \mathrm{C}$ values in $1590,1815,1895,1925$ and 1949. A comparison with Volcanic Eruption Index of tropical events (Smithsonian Catalogue (Simkin and Sibert 1994)) shows a nice fit with these periods. Eruptions in 25 Vanuatu and Indonesia in the years preceding 1590, the Tambora (1815 Indonesia) and finally several eruptions in Papua New Guinea, Indonesia, New Zealand and Vanuatu in 1894-1895, 1925 and 1949 all seem to have a $\delta^{13} \mathrm{C}$ signature in the lle des Pins coral. Volcanic dust-load to the atmosphere can affect the radiative balance, thus providing a
3, 1021-1035, 2007

\section{Solar minima and coral carbon isotopes}

T. Ourbak et al.

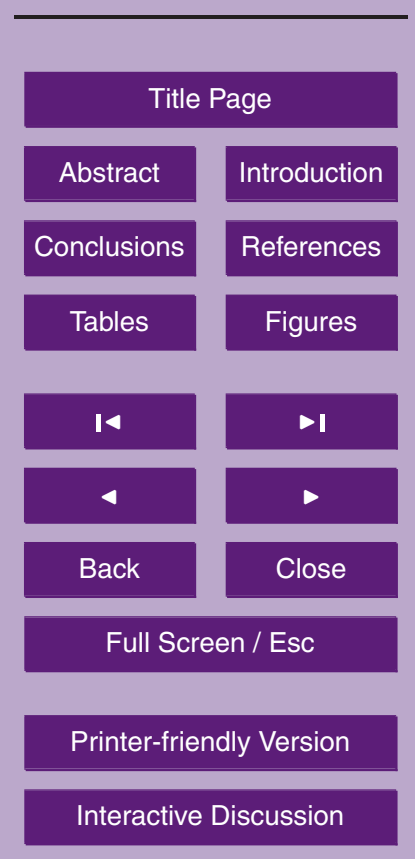


mechanism to alter photosynthesis and $\delta^{13} \mathrm{C}$ in corals. Our result confirms the work of Crowley et al for volcanic impact in isotopes contained in corals (Crowley et al., 1997) even if all the eruptions present in the $\delta^{18} \mathrm{O}$ record in their studies do not have a direct impact on our core.

\section{Conclusions}

This study presents the potential impact of long-term solar radiation variations over metabolic processes in a coral from the southwest Pacific Ocean. The $\delta^{13} \mathrm{C}$ results show a long term increase following solar radiation increase from 1475 until about 1860. Since $1860, \delta^{13} \mathrm{C}$ decreased probably due to the Suess effect. During two periods of low solar activity (namely the Spörer and Maunder minima), a rapid change in coral metabolic activity from autotrophy towards heterotrophy happened, when light availability became insufficient. Biological recovery lasted few years. Some other $\delta^{13} \mathrm{C}$ negative peaks can be correlated with tropical volcanic eruptions, confirming the link between light levels and mode of feeding in corals. We also support the idea that 15 systematic presentation of $\delta^{13} \mathrm{C}$ vs. $\delta^{18} \mathrm{O}$ plots would give relevant information on heterotrophical versus autotrophical patterns.

Acknowledgements. This work was supported by the Institut de Recherche pour le Developpement (IRD). The authors would like to thank K. Charlier for help in analyses, S. Reynaud and $\mathrm{K}$. DeLong for comments on a previous version of the manuscript and Météo France for insola20 tion data.

\section{References}

Anthony, K. R. N. and Fabricius, K. E: Shifting roles of heterotrophy and autotrophy in coral energetics under varying turbidity, J. Experimental Marine Biology and Ecology, 252(2), 221$253,2000$.
3, 1021-1035, 2007

\section{Solar minima and coral carbon isotopes}

T. Ourbak et al.

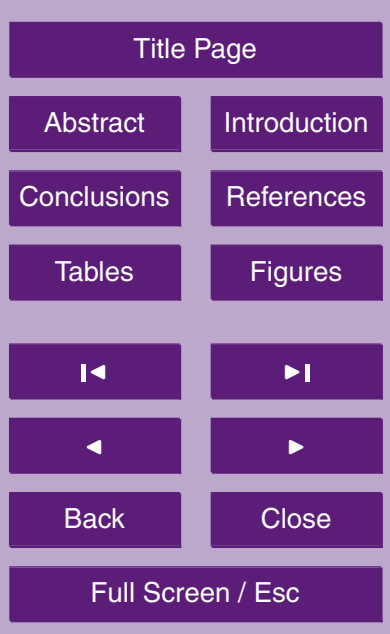

Printer-friendly Version

Interactive Discussion 
Bard, E., Raisbeck, G., Yiou, F., and Jouzel, J.: Solar irradiance during the last $1200 \mathrm{yr}$ based on cosmogenic nuclides, Tellus B 52, 985-992, 2000.

Beck, J. W., Edwards, R., Ito, E., Taylor, F., Recy, J., Rougerie, F., Joannot, P., and Henin, C.: Sea surface temperature from coral skeletal Strontium/Calcium ratios, Science, 257,644647, 1992.

Bohm, F., Joachimski, M. M., Lehnert, H.,Morgenroth, G., Kretschmer, W., Vacelet J., and Dullo, W.-C.: Carbon isotope records from extant Caribbean and South Pacific sponges: Evolution of [delta]13C in surface water DIC, Earth Planet Sc. Lett., 139, 1-2, 291-303, 1996.

Boiseau, M., Juillet-Leclerc, A., Yiou, P., Salvat, B., Isdale, P., and Guillaume, M.: Atmospheric and oceanic evidences of El Niño-Southern Oscillation events in the south central Pacific Ocean from coral stable isotopic records over the last 137 years, Paleoceanography, 136, 671-685, 1998.

Carriquiry, J., Risk, M. J., and Schwarcz, H. P.: Stable isotope geochemistry of corals from Costa Rica as proxy indicator of the EL Niño/Southern Oscillation (ENSO), Geochim. Cosmochim. Ac., 58(1), 335-351, 1994.

Cohen, A. L. and Hart, S. R.: The effect of colony topography on climate signals in coral skeleton, Geochim. Cosmochim. Ac., 61(18), 3905-3912, 1997.

Corrège, T., Quinn, T., Delcroix, T., Le Cornec, F., Récy, J., and Cabioch, G.: Little Ice Age sea surface temperature variability in the southwest tropical Pacific, Geophys. Res. Lett., 28 18, 3477-3480, 2001.

Crowley, T., Quinn, T., Taylor, F. W., Henin, C., and Joannot, P.: Evidence for a volcanic cooling signal in a 335-year coral record from New Caledonia, Paleoceanography, 12(5), 633-639, 1997.

DeLong, K., Quinn, T. M., and Taylor, F. W.: Reconstructing 20th Century SST Variability in the Southwest Pacific: A Replication Study Using Multiple Coral Sr/Ca Records from New Caledonia, Paleoceanography, doi:10.1029/2007PA001444, accepted, 2007.

Fairbanks, R. G. and Dodge, R. E.: Annual periodicity of the ${ }^{18} \mathrm{O} /{ }^{16} \mathrm{O}$ and ${ }^{13} \mathrm{C} /{ }^{12} \mathrm{C}$ ratios in the coral Montastrea annularis, Geochim. Cosmochim. Ac., 43, 1009-1020, 1979.

Fallon, S. J., Guilderson, T. P., and Caldeira, K.: Carbon isotope constraints on vertical mixing and air-sea CO2 exchange. Geophys. Res. Lett, 30(24), 2289, doi:10.1029/2003GL018049, 2003.

Felis, T., Patzold, J., Loya, Y., and Wefer, G.: Vertical water mass mixing and plankton blooms recorded in skeletal stable carbon isotopes of a Red Sea coral, J. Geophys. Res., 103,

\section{Solar minima and} coral carbon isotopes

T. Ourbak et al.

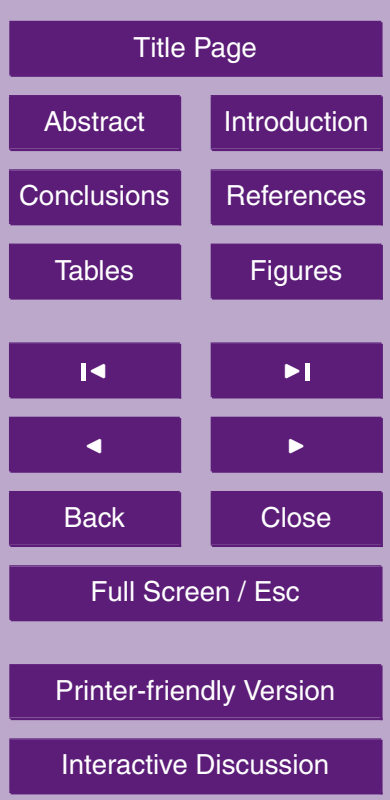


$30731-30739,1998$.

Gagan, M. K., Chivas, A. R., and Isdale, P. J.: High-resolution isotopic records from corals using ocean temperature and mass-spawning chronometers, Earth Planet Sc. Lett., 121, 549-558, 1994.

5 Ghil, M., Allen, R. M., Dettinger, M. D., Ide, K., Kondrashov, D.,Mann, M. E., Robertson, A.,Saunders, A., Tian, Y., Varadi, F., and Yiou, P.: Advanced spectral methods for climatic time series, Rev. Geophys, 40(1), 3.1-3.41, doi:10.1029/2000GR000092, 2002.

Grottoli, A. G.: Stable Carbon isotopes $\left(\delta^{13} \mathrm{C}\right)$ in coral skeletons, Oceanography, 13(2), 93-97, 2000.

10 Grottoli, A. G.: Effect of light and brine shrimp on skeletal $\delta^{13} \mathrm{C}$ in the Hawaiian coral Porites compressa: a tank experiment, Geochi mica et Cosmochimica Acta, 66(11), 1955-1967, 2002.

Gruber, N., Keeling, C., Bacastow, R., Guenther, P., Lueker, T., Wahlen, M., Meijer, H., Mook, W., and Stocker, T.: Spatiotemporal patterns of carbon-13 in the global surface oceans and 15 the oceanic Suess effect, Global Biogeochem. Cy., 13, 307-335, 1999.

Guilderson, T. P. and Schrag, D. P.: Reliability of coral isotope records from the western Pacific warm pool: A comparison using age-optimised records, Paleoceanography, 14(4), 457-464, 1999.

Kieth, M. L. and Weber, J. N.: Systematic relationships between carbon and oxygen isotopes

20 in carbonates deposited by modern corals and algae, Science, 150, 498-501, 1965.

Lean, J., Beer, J., and Bradley, R.: Reconstruction of Solar Irradiance since 1610: Implications for Climate Change, Geophys. Res. Lett., 22(23), 3195-3198, 1995.

McConnaughey, T. A.: ${ }^{13} \mathrm{C}$ and ${ }^{18} \mathrm{O}$ isotope disequilibria in biological carbonates. 1. Patterns, Geochim. Cosmochim. Ac., 53, 151-162, 1989.

25 McConnaughey, T. A., Burdett, J., Whelan, J. F. and Paull, C. K.: Carbon isotopes in biological carbonates: Respiration and photosynthesis. Geochim. Cosmochim. Ac., 61(3), 611-622, 1997.

Müller, A., Gagan, M., and Lough, J. M.: Effect of early marine diagenesis on coral reconstructions of surface-ocean $13 \mathrm{C} / 12 \mathrm{C}$ and carbonate saturation state, Global Biogeochem. Cy., $30 \quad 18,2004$.

Ourbak, T., Corrège, T., Malaizé, B., Le Cornec, F., Charlier, K., and Peypouquet, J.: A highresolution investigation of temperature, salinity and upwelling activity proxies in corals, Geochemistry, Geophysics, Geosystems, 7(3), Q03013, doi:10.1029/2005GC001064, 2006.

\section{Solar minima and} coral carbon isotopes

T. Ourbak et al.

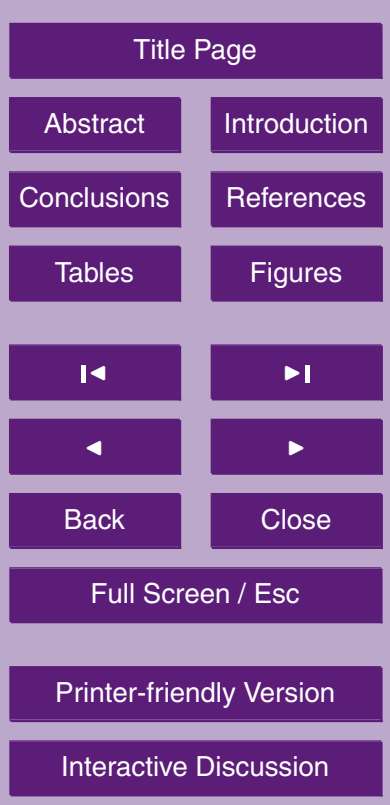


Pelejero, C., Calvo, E., McCulloch, M. T., Marshall, J. F., Gagan, M. K., Lough, J. M., and Opdyke, B. N.: Preindustrial to Modern Interdecadal Variability in Coral Reef pH., Science, 309(5744), 2204-2207, 2005.

Quinn, T. M., Crowley, T. J., Taylor, F. W., Henin, C., Joannot, P., and Join, Y.: A multicentury stable isotope record from a New Caledonia coral: Interannual and decadal sea surface temperature variability in the southwest Pacific since 1657 A.D., Paleoceanography, 13(4), 412-426, 1998.

Rau, G. H., Tessie, J. L., Rassoulzadegan, F., and Fowle, S. W.: 13C/12C and 15N/14N variations among size-fractionated marine particles: Implications for their origin and trophic relationships, Mar. Ecol. Prog. Ser., 59, 33-38, 1990.

Reynaud-Vaganay, S., Juillet-Leclerc, A., Jaubert, J., and Gattuso, J.-P.: Effect of light on skeletal $\mathrm{d} 13 \mathrm{C}$ and $\mathrm{d} 18 \mathrm{O}$, and interaction with photosynthesis, respiration and calcification in two zooxanthellate scleractinian corals, Palaeogeography, Palaeoclimatology, Palaeoecology, 175, (1-4), 393-404, 2001.

Risk, M. J., Sherwood, O. A., Heikoop, J. M., and Llewellyn, G.: Smoke signals from corals: isotopic signature of the 1997 Indonesian "haze" event, Mar. Geol., 202, (1-2), 71-78, 2003.

Simkin, T. and Sibert, L.: Volcanoes of the World: a Regional Directory, Gazetteer and chronology of Volcanism during the last 10000 years, Tuscon, Arizona, Geoscience Press, 1994.

Swart, P. K.: Carbon and oxygen isotope fractionation in scleractinian corals: a review, EarthSci. Rev., 19, 51-80, 1983.

Swart, P. K., Leder, J. J., Szmant, A. M., and Dodge, R. E.: The origin of variations in the isotopic record of scleractinian corals: II. Carbon, Geochim. Cosmochim. Ac., 60(15), 2871$2885,1996$.

Weber, J. N. and Woodhead, P. M. J.: Diurnal variations in the isotopic composition of dissolved inorganic carbon in seawater from coral reef environments, Geochim. Cosmochim. Ac., 35, 891-902, 1971.

\section{Solar minima and coral carbon isotopes}

T. Ourbak et al.
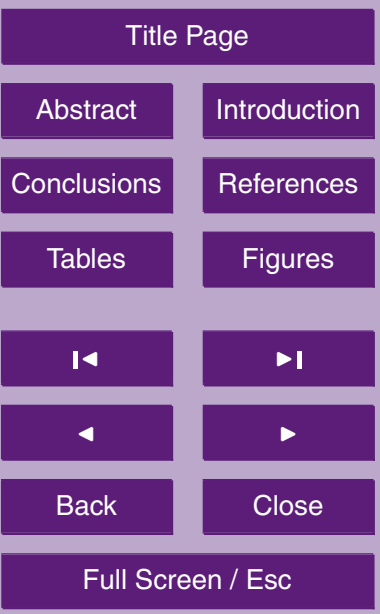

Printer-friendly Version

Interactive Discussion 


\section{Solar minima and coral carbon isotopes}

T. Ourbak et al.

Table 1. Correlation coefficient $(r)$ between stable isotopes in lle des Pins coral $\left(\delta^{18} \mathrm{O}\right.$ and $\delta^{13} \mathrm{C}$ ) and environmental variables (solar radiation and SST) $n=74, p<0.001$ for the 19962002 period. One can note the weak $r$ value between SST and solar radiation which is due to $\approx 2$ months lag (thermal inertia of ocean waters).

\begin{tabular}{lcccc}
\hline & $\delta^{13} \mathrm{C}$ & $\delta^{18} \mathrm{O}$ & Solar radiation & $\mathrm{SST}$ \\
\hline$\delta^{13} \mathrm{C}$ & 1 & & & \\
$\delta^{18} \mathrm{O}$ & 0.28 & 1 & & \\
Solar radiation & 0.54 & -0.33 & 1 & \\
SST & 0.07 & -0.79 & 0.49 & 1 \\
\hline
\end{tabular}

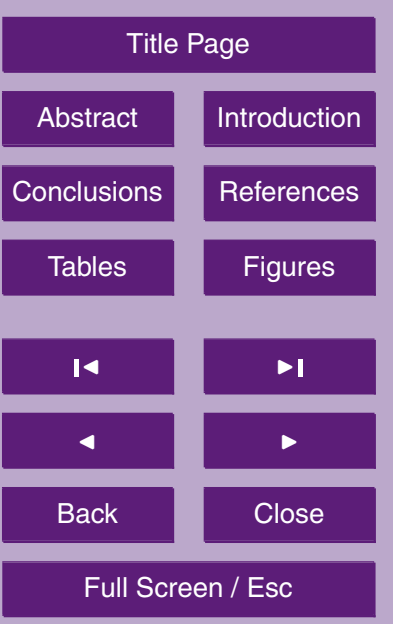

Printer-friendly Version

Interactive Discussion 

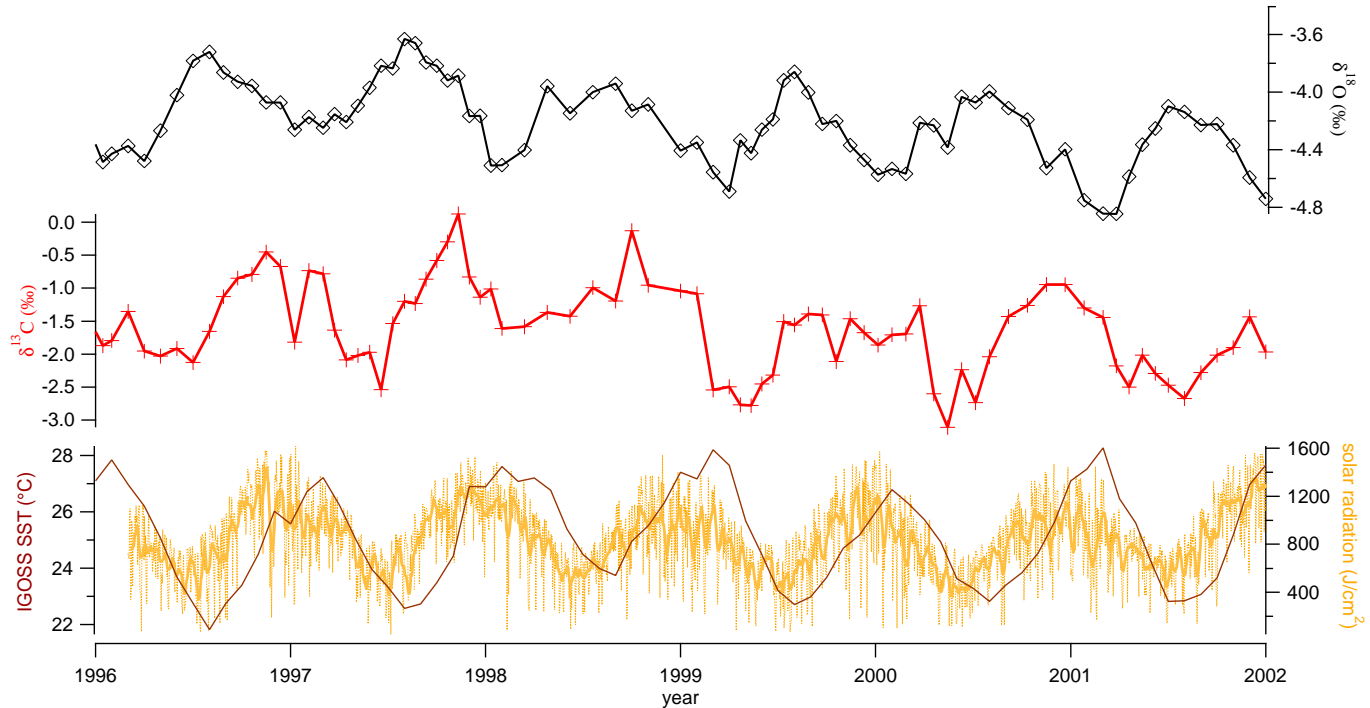

Fig. 1. Monthly $\delta^{18} \mathrm{O}, \delta^{13} \mathrm{C}$, IGOSS SST and daily insolation time series from lle des Pins. Note that $\delta^{18} \mathrm{O}$ is inversely correlated to SST (see Table 1), note also the lag between insolation peaks and SST.
3, 1021-1035, 2007

\section{Solar minima and} coral carbon isotopes

T. Ourbak et al.

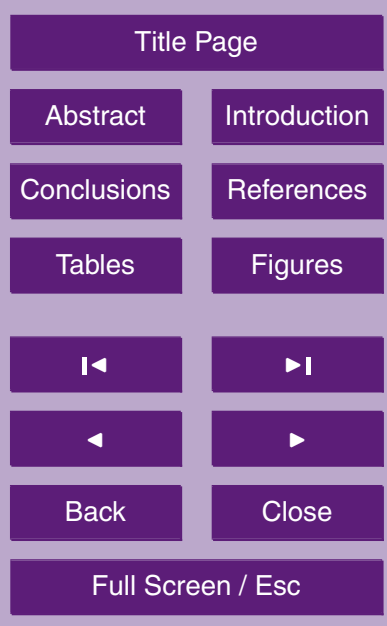

Printer-friendly Version

Interactive Discussion 


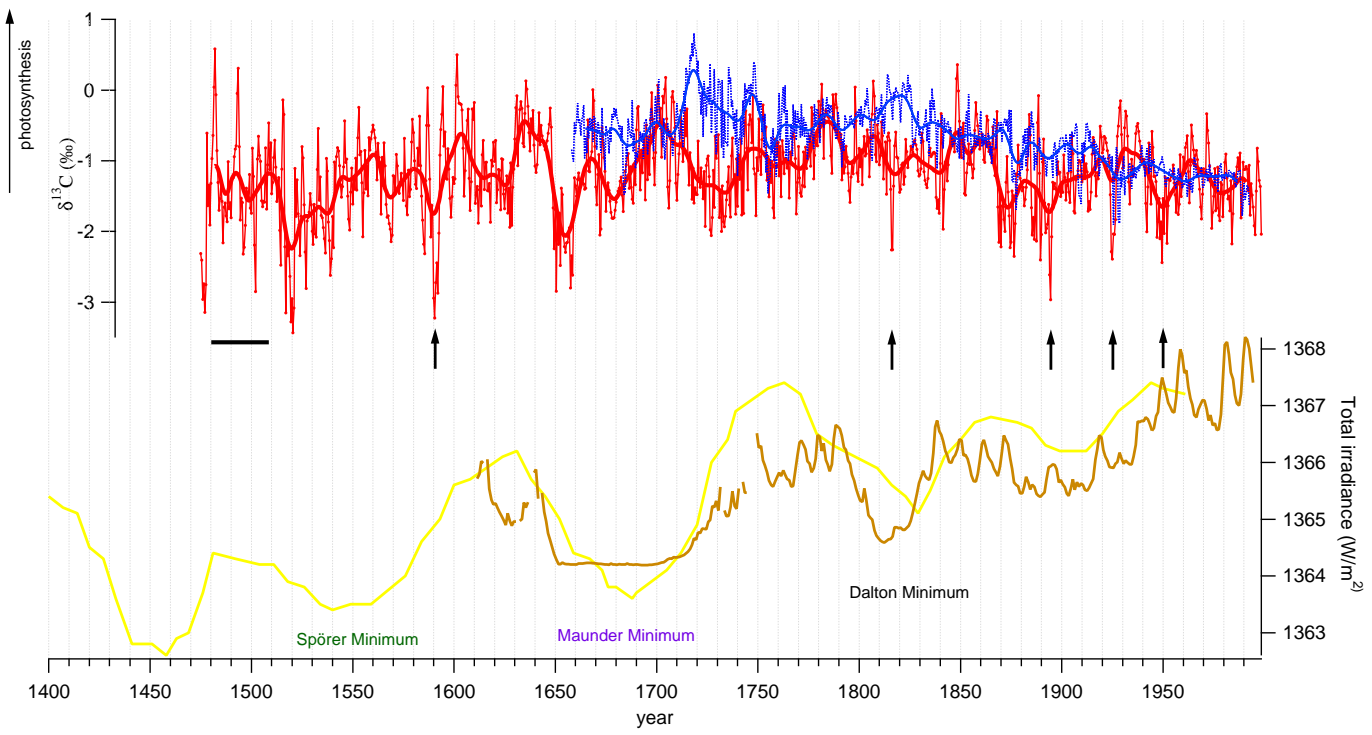

Fig. 2. $\delta^{13} \mathrm{C}$ time series of the lle des Pins (red) and Amedee cores (blue). Bold lines represent 29 points Hanning filters to emphasize periodicities higher than 7 years. Bottom: reconstructed solar irradiance derived from South Pole ice core (Bard et al., 2000), in yellow, and from (Lean et al. 1995), in orange with Spörer, Maunder and Dalton minima. Arrows denote timing of tropical volcanic eruptions (Simkin and Sibert, 1994) potentially affecting $\delta^{13} \mathrm{C}$ signal. Horizontal black bar represents chronological uncertainty range at the bottom of the core.

\section{Solar minima and} coral carbon isotopes

T. Ourbak et al.

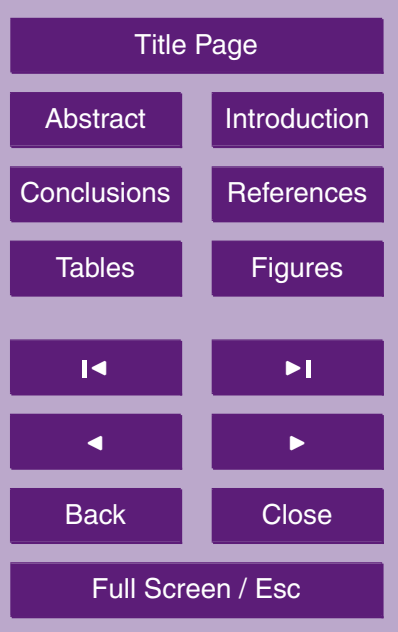

Printer-friendly Version

Interactive Discussion 


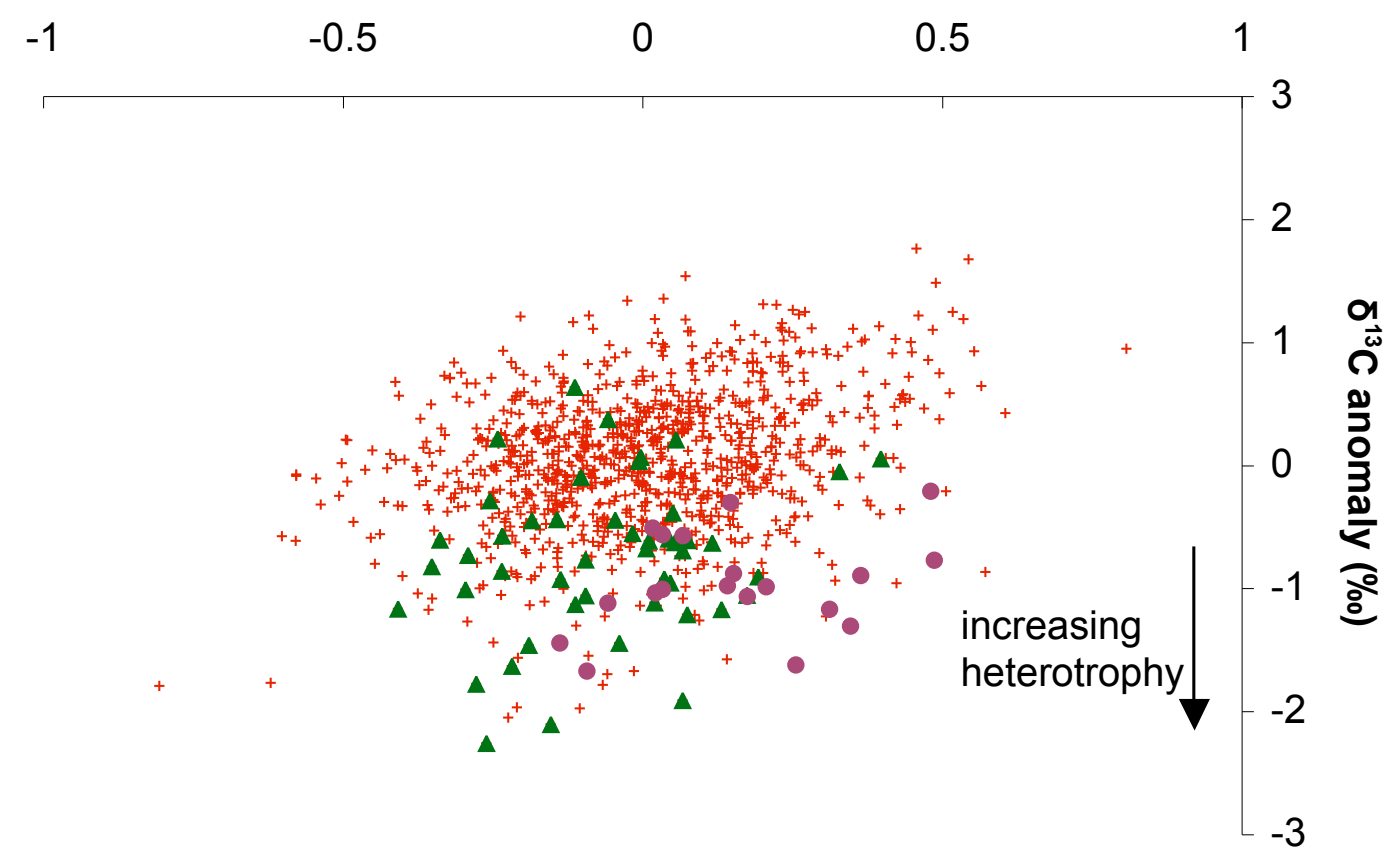

\section{Solar minima and} coral carbon isotopes

T. Ourbak et al.

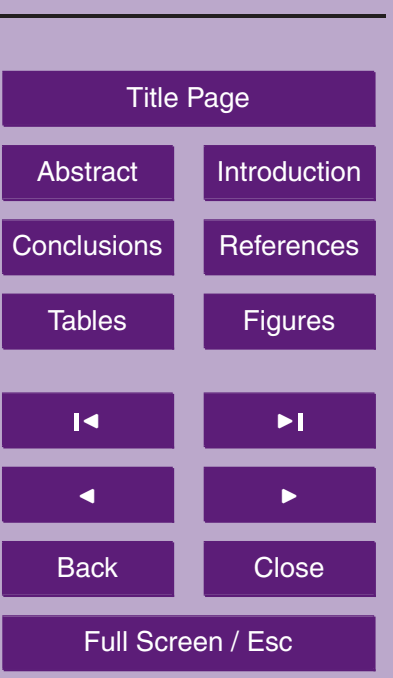

Fig. 3. Cross-plot of $\delta^{13} \mathrm{C}$ vs. $\delta^{18} \mathrm{O}$ for the lle des Pins coral. Whole data (crosses) together with data corresponding to peaks attributed to Spörer (triangles) and Maunder minima (circles) are shown in anomaly with respect to the mean.
Printer-friendly Version

Interactive Discussion 